\title{
Two New severe leaf spot diseases on forest trees of Seoni Forest (MP)
}

\section{S. A. Firdousi ${ }^{*}$ and V.M Kamle ${ }^{1}$}

${ }^{1}$ DR.AG.Bendale Mahila College

JALGAON

*H. J. Thim College of Arts and Science

MEHRUN, JALGAON

${ }^{*}$ Corresponding Author

Email : shakeeltalk@gmail.com

Received : 08.10.2019; Accepted : 04.11.2019

\section{ABSTRACT}

During the survey of the forest fungal disease, of Seoni district,(M.P), two severe leaf spot diseases on Chroloxylonswietinia and of Adina cordifoliaRox were observed in Seoni, forest Seoni(M.P) during July to September.201718. The casual organism was identified as Psuedocercosporachloroxyliae and MycovellosiellaadinaeFirdousi respectively which were identified with the help of literature and confirmed by the experts. This is first report from Seoni and Madhya Pradesh..

\section{Introduction}

The forest of Seoni is a tropical dry deciduous type forest. The vegetation varies with changes in altitudes, topography and rainfall. There are various sub types of forest in this area.The Seoni district is located in the southern part of Madhya Pradesh. The district extends over an area of $8758 \mathrm{~km}$. It is boardered by Jabalpur. Narsingpur and Mandla districts to north , Balaghat to east and Chhindwara to the west and the boundary with Nagpur. It has about 37\% forest cover.National highway44 to Kanyakumari passes through the district. The north part of Seoni consists of a large trap hills and the crystalline roack.

The Fungi play important role in various disease and responsible for great loss. Many diseases are like leaf spot, leaf blight, leaf rust, shot hole and marginal infection. They cause yearly leaf fall. Most of The fungi are follicolous fungi belonging to Cercospora allied complex and coelomycetes. There are many parasitic fungi causing various types of foliage diseases. In the forest of this area are small to large trees found commonly in the mixed deciduous forest and used in the various ways. Its wood is used for agriculture and domestic implements. A severe leaf spot disease was found in the forest of Seoni. The causal organism was identified as Psuedocercosporachloroxyliae and Mycovellosiellaadinae ${ }^{5}$.

It is a small to medium sized deciduous tree growing commonly in the forest. The plant has straight to crooked trunk and produces sucker in forest and regenerates. The tree is famous for hard wood which is used in cart and building material. It is also used for agriculture implements. The leaves are used for fodder.

\section{Material and Method}

A frequent, extensive and intensive survey was made to collect the phytopathogenic fungi infecting the leaves in the different forest sites of Seoni forest. The symptomology and other informations such as place of the collection, locality, local name of the plants their families, date of collection were noted in the field diary. The samples were kept in the polythene bags and carried to the laboratories for identification. The pathogens were identified with the help of various monographs, reviews, books and research papers ${ }^{2,3}$.

\section{Result and Discussion}

Leaf spot of Chroloxylonswietinia is caused by Psuedocercosporachloroxyliae

The infection first appears as a small necrotic spot 
on the lower surface of the leaf in August and spot coalesce gradually. Spots are mostly irregular and colonies are hypophyllous.

Infection spot amphienous, small to large brown, mostly vien limited colonies, hypophyllous, puntoformis, mycelim immersed, narrow, septate and branched, stoma well developed, partly erumpent,psyedoparenchymatous, mid olavaceous, 20-80 mm. conodiophorecaesptose, densely packed, sporodochia, macronematous, short to stumpy, erect to sub erect straight to flexous, mostly, septate, unbranched, smooth walled light olivaceous, cylindrical straight, light olavaceous,3-60×2-8 mm. conidegeounous, intergraded, terminal monoblastic, cylinderic, conidia, simple solitary, dry, acrogenous, light olavaceous,, cylindrical, straight to curve., smooth walled,15-88×2-6 mm. septate, acute, base truncate, hila unthickened. This is first record of leaf spot disease not only from Seoni but Madhya Pradesh.

\section{Leaf spot of Adinacordifoliarox. Caused by MycovellosiellaadinaeFirdousi.}

Adina cordofolia is a large deciduous tree with a large crow belonging to family Rubiaceae The tree is used for fuel and timber. The trees are found generally scattered in the forest. A highly severe leaf spot disease was found on this host and causal organism was identidied as Mycovellosiellaadinae ${ }^{6}$.

\section{Symptoms}

Infection spots are amphigenous. They are light brown to dull brown, small to large covering the whole leaf area. Colonies are hypophyllous. These spots appear in the month of October and remain upto February. Hyphae of the causal organism partly immersed and partly superficial. Narrow septate, stroma erumpent, conidiophore caespitose in loose fascieles, conidegenous cells intergrated. Terminal, conidia simple solitary to catenate light olivaceous, cylindidric. To fusiform ,dry smooth walled 1-7 eptate,

\section{References}

1. Bakshi BK. Forest Pathology : Principal and Practice I Forestry, Controller of Publication Delhi. 1976.

2. Chupp C. A Monograph of the fungus, Cercospora, Ithaka, New York. 1953.

3. Ellis MB. DematacousHyphomycetes, CMI, Kew, England. 1971.

4. MB. More DematiceousHypomycetes CMI Kew England. 1976

5. Firdousi SA, Khan TA. Flora and Fauna. 2015; 21 : 158-160.

6. Firdousi SA. A new species of Stigmina from India', Flora \& Fauna. 2014; 20 (1) : 28-30

7. Hunter HL, Hunter BB. Illustrated .genera of imperfecti Fungi, St Paul press, Minnasota. 2010.

8. Jamaluddin Rizvi, Bilgrami. Fungi of India host Index and Addenda, Bisen Pal Singh Publication, Dehradun. 2008. 